\begin{tabular}{l} 
RCCS \\
\hline Annual Review
\end{tabular}

\section{RCCS Annual Review}

A selection from the Portuguese journal Revista Crítica de Ciências Sociais

$7 \mid 2015$

Issue no. 7

\title{
Bridging the Chasm between Domestic and International Approaches to Peacebuilding: Conceptual and Institutional Tools
}

\author{
Necla Tschirgi
}

\section{(2) OpenEdition}

\section{Journals}

\section{Electronic version}

URL: http://journals.openedition.org/rccsar/605

DOI: $10.4000 /$ rccsar.605

ISSN: $1647-3175$

\section{Publisher}

Centro de Estudos Sociais da Universidade de Coimbra

\section{Electronic reference}

Necla Tschirgi, «Bridging the Chasm between Domestic and International Approaches to

Peacebuilding: Conceptual and Institutional Tools », RCCS Annual Review [Online], 7 | 2015, Online since 01 October 2015, connection on 19 April 2019. URL : http://journals.openedition.org/rccsar/605; DOI : 10.4000/rccsar.605 


\section{Necla Tschirgi}

Joan B. Kroc School of Peace Studies, University of San Diego, USA

\section{Bridging the Chasm between Domestic and International Approaches to Peacebuilding: Conceptual and Institutional Tools}

This paper focuses on the chasm between domestic and international understandings and approaches to peacebuilding and the mixed outcomes that characterize contemporary efforts to assist war-torn countries. It argues that post-Cold War peacebuilding relies on a wide array of international actors with diverse interests and mandates which are not necessarily aligned with local realities or needs. Building on the rich literature on the role of external actors in conflict zones, the paper examines the interface between domestic and international actors through the concept of hybridity. It then reviews two mechanisms that aim to level the playing field between war-affected countries and international actors: the United Nations Peacebuilding Commission and the New Deal for Engagement with Fragile States.

Keywords: conflict resolution; fragile states; peacebuilding; Peacebuilding Commission.

\section{Introduction}

Since its entry into the international policy lexicon with former UN Secretary-General Boutros-Boutros Ghali's much-cited report An Agenda for Peace in 1992, the term "peacebuilding" has steadily gained currency among diverse constituencies ranging from international development agencies to local non-governmental organizations. Concurrently, an impressive body of literature has been produced, generating major debates on the key features, main achievements and limitations of peacebuilding. ${ }^{1}$ Interestingly, there is still no commonly accepted definition of peacebuilding which has led to the concept's steady expansion to include a spectrum of activities from conflict prevention to post-conflict reconstruction (Barnett et al., 2007). After September 2011, the concept was stretched even further as it became conflated with state-building, nation-building, regime change and humanitarian intervention. It is now used indiscriminately in the context of war-fighting in Afghanistan, peace operations in Darfur as well as long-term institution-building in Sierra Leone and Timor-Leste, which severely strains the concept's utility and credibility. Nonetheless, peacebuilding continues to be a compelling - albeit controversial - issue area for policy makers, practitioners and academics alike.

This paper focuses on a problem that continues to preoccupy both the theory and practice of peacebuilding, namely, the chasm between domestic and international

\footnotetext{
* Article published in Portuguese in RCCS 104 (September 2014). DOI: 10.4000/rccs.5672

${ }^{1}$ For a useful review of the origins and history of peacebuilding, see www.peacebuildinginitiative.org.
} 
understandings and approaches to peacebuilding and the mixed outcomes that characterize contemporary efforts to assist countries emerging from violent conflict. The paper rests on the premise that post Cold War peacebuilding is distinctive in its heavy reliance on the engagement of the international community. ${ }^{2}$ It is increasingly difficult to talk of contemporary peacebuilding without reference to the wide array of international actors who have come to play an important role in war-affected countries. These actors generally have diverse (and, at times, conflicting) values, interests and mandates which are not necessarily aligned with local realities, needs or goals. Much has been written about the intended or unintended consequences of the engagement of external actors in conflict zones (Uvin, 1999; Anderson, 1999). Building on that literature, this paper turns its focus more narrowly on the interface between domestic and international actors through the lens of the concept of hybridity and two new mechanisms aiming to level the playing field between conflictaffected countries and their international partners.

The paper consists of four sections. The first section provides a quick overview of the aspirations and limitations of international peacebuilding with a view to placing the paper's problematique within both practice and research. The second section reviews current debates on hybridity as an opportunity to re-think the misleading external vs. internal, insider vs. outsider, top down vs. bottom up dichotomies that characterize contemporary peacebuilding discourse. Taking hybridity as a useful lens to investigate the complex but asymmetric encounter between domestic and international agendas, the third section examines two new mechanisms that aim to strengthen the voices of conflict-affected countries in the design and delivery of international assistance for peacebuilding. Finally, the last section offers some concluding comments about the future of peacebuilding.

\section{The International Peacebuilding Project: An Overview}

The post-Cold War peacebuilding agenda was shaped more by necessity than by deliberate design. Throughout the 1990s, as protracted Cold War conflicts came to an end and intrastate conflicts, "new wars" and complex emergencies were catapulted to center stage in international affairs, there was heightened demand for the United Nations and other

\footnotetext{
${ }^{2}$ The term "international community" is a problematic term even though it is used widely. In this paper, it refers to external actors only to distinguish them from domestic actors. Neither external nor domestic actors are monolithic or homogeneous, which is why their variegated interaction is the subject of this paper.
} 
international actors to assume a concerted role in assisting conflict-affected countries. Initially, it was not clear what form that assistance would take and how it would fit within existing policy and programming tools and instruments. Nonetheless, the United Nations, other international and regional organizations, donor agencies, non-governmental organizations and front-line development, human rights and humanitarian practitioners became engaged in a range of activities, projects and programs that went beyond the compartmentalized system of international assistance that had been in place since the end of World War II. Peacebuilding emerged in this highly fluid context and proved to be a particularly useful concept in so far as it pushed the boundaries of Cold War orthodoxies.

Initially peacebuilding was presented in An Agenda for Peace within a progression of discrete interventions from peacemaking and peacekeeping to post-conflict peacebuilding. Yet, in practice international actors quickly confronted the fact that post Cold War conflicts were not unilinear in nature; nor could they be addressed sequentially. Recognizing the limitations of fragmented mandates and institutional silos, early peacebuilders started to work at the still-uncharted nexus between humanitarian assistance, development and security (Jenkins, 2013; Tschirgi, 2004). Going beyond state-centric perspectives, a growing number of international actors sought to address intra-state conflicts through novel multisectoral approaches, including multi-dimensional peace operations. The new peacebuilding agenda offered an unusual opportunity for innovative multilateral action at a time when long-established Cold War policies and instruments were clearly inadequate to address intrastate conflicts and civil wars. Thus, in the decade after the Cold War, peacebuilding heralded a new era in international cooperation and multilateral assistance. As diverse actors working on human rights, humanitarian affairs, conflict resolution, peacekeeping or development became engaged in conflict-affected countries, there was a proliferation of activities, projects, programs and policies at the intersection of security and development that collectively came to be known as peacebuilding. ${ }^{3}$

Notwithstanding its strong internationalist rhetoric, peacebuilding was essentially a Western project and was implemented primarily through the existing system of international organizations, donor agencies, and various governmental and non-government organizations. Although highly fragmented, ad hoc and experimental in nature, the

\footnotetext{
3 In this paper, the term international peacebuilding encompasses multi-dimensional peace operations, including peacemaking and peacekeeping as part of the larger peacebuilding agenda.
} 
internationally driven peacebuilding agenda was largely influenced by the concept of liberal peace and found resonance in the liberalizing ethos of post-Cold War international affairs (Richmond, 2011; Tadjbakhsh, 2011; Baranyi, 2008). From Mozambique and Cambodia to El Salvador, international actors supported policies and programs which reflected a strong commitment to liberal values, including good governance, rule of law, human rights, political participation, free and fair elections, gender equality, free markets, transparency and accountability.

Not surprisingly, the liberal aspirations of international peacebuilding did not find fertile ground in countries with highly-conflicted political orders and deep-rooted socio-economic problems. As lessons from conflict-affected countries started to come in, the heady optimism of the early 1990s gave way to serious concerns about the suitability and sustainability of the externally-driven liberal peacebuilding project. Meanwhile, a growing number of evaluation studies were instrumental in revealing the meager record of international peacebuilding efforts (Goodhand, 2001; Søbøm, 1998; Smith, 2003; Waller, 2000). Thus, as the demand for international peacebuilding assistance continued to grow, there were serious questions about its effectiveness and impact.

Given peacebuilding's practical origins, the academic community was a latecomer to the field. However, as evidence from the field accumulated, there was rapid proliferation of the academic literature at the intersection of theory, policy and practice. That literature is as rich as it is diverse. Nonetheless, it has two distinct streams which represent divergent perspectives on peacebuilding: the conventional problem-solving approach and the critical approach (Newman et al., 2009). The conventional approach accepts peacebuilding as an essential part of the liberal international agenda of the post-Cold War era and focuses primarily on the deficiencies in its implementation. Researchers have convincingly documented the shortcomings of international peacebuilding, which range from the absence of a coherent strategy and adequate resources to the lack of coordination among external actors who play prominent roles in conflict-affected countries. This body of literature has come to be known as the conventional "problem-solving" approach since it upholds the view that peacebuilding's shortcomings can be alleviated through more effective policies, practices and institutions (Newman et al., 2009; Tadjbakhsh, 2011).

The problem-solving literature has been highly influential. Policymakers and practitioners have drawn on insights from an ever-expanding body of academic, operational and 
evaluation studies in designing and implementing successive peacebuilding interventions. Concurrently, there have been important reform initiatives including the creation of the UN's new "peacebuilding architecture" (comprising the Peacebuilding Commission, the Peacebuilding Fund and the Peacebuilding Support Office), adoption of new policy guidelines on peacekeeping and peacebuilding, and greater attention to implementation issues (Tschirgi, 2004; Cutillo, 2006). Meanwhile, evidence from concrete country contexts allowed researchers and academics to undertake comparative analyses of what works and what does not work in different environments. As a result, there has been considerable crossfertilization and mutual influence among policy, practice and research leading to a distinct epistemic community around mainstream peacebuilding.

One of the issues that gained heightened attention among policymakers as well as the problem-solving research community was the disconnect between international and local approaches to peacebuilding. While it was repeatedly asserted that peacebuilding is a homegrown process, peacebuilding strategies were often designed and implemented by external actors with only limited or perfunctory consultation with national counterparts. Although it was not clear what local ownership involved, the mantras of ownership and partnership, coordination and coherence, harmonization and alignment quickly became the indispensable principles of mainstream peacebuilding discourse and practice (Chesterman, 2007; Donais, 2009). The issue of local ownership was particularly salient for the UN's Peacebuilding Commission as it became engaged in Sierra Leone and Burundi as the first countries on its agenda.

Yet, ongoing reforms did not translate readily into more effective peacebuilding outcomes. As the gap between the ambitions and actual record of international peacebuilding persisted despite important innovations, a parallel body of literature emerged to question the main assumptions of international peacebuilding. Initially operating on the margins of the mainstream discourse, this critical approach to peacebuilding has steadily gained ground. The new critical literature challenges the very basis of the liberal peacebuilding agenda by raising questions about what type of peace is being built and whether the model promoted by the international community is sustainable (Bendaña, 2003; Richmond, 2006; Tadjbakhsh, 2011). After 9/11, this debate was further affected by the conflation of peacebuilding with international security concerns with the launch of the global war on terror (Tschirgi, 2013). As peacebuilding became securitized with increased 
reliance on the use of force, analysts began to question the motivations and objectives of the international peacebuilding agenda and interrogated the viability of the liberal peacebuilding model in conflict-affected non-Western societies (Tschirgi, 2013; Baranyi, 2008). It was contended that mainstream peacebuilding strategies were not only inappropriate to address the multi-faceted and structural problems facing countries emerging from conflict, but that they might in fact contribute to the perpetuation of those structural problems.

Thus, critical researchers turned their attention to the underlying normative and structural issues, rather than the operational challenges, that afflicted international peacebuilding. Among other things, these included global as well as domestic power asymmetries, the economic drivers of conflict, and the impacts of the policies of key states and international organizations on conflicts in peripheral regions. Unlike the conventional pragmatic approach that sought solutions to improve peacebuilding's effectiveness, the critical approach argued that the strategies promoted by liberal peacebuilding were flawed since they were out of sync with local realities, needs and aspirations and did not take into account the central issue of legitimacy (Pugh, 2013; Newman et al., 2009; Tadjbakhsh, 2011).

Insights from both the conventional and the critical approaches have inspired important debates and unresolved controversies on what constitutes sustainable peace and how it might be attained. In reality both approaches are considerably more diverse and heterogeneous than is suggested in the quick review above. Where they do converge, however, is their shared concern for the intended or unintended consequences of international peacebuilding on conflict-affected societies and the need to ground peacebuilding in local realities. In advancing a liberal peacebuilding agenda, the mainstream approach has called for differentiated international strategies based on context-specific, locally-informed and conflict-sensitive efforts in collaboration with local partners. Meanwhile, critical scholars have increasingly argued that peacebuilding can at best generate hybrid outcomes as a result of the encounter between the aspired liberal agenda and the complex political dynamics in conflict-affected countries. In short, notwithstanding the formulaic rhetoric in many policy documents, there is growing understanding that peacebuilding is not a monolithic enterprise but a messy process with unpredictable outcomes (Newman, 2009: 46). In that light, the concept of hybridity offers an interesting 
prism through which to re-examine the viability of the peacebuilding agenda two decades after it gained widespread currency.

In specific, hybridity provides a new perspective to understand the asymmetrical but interdependent relations between the diverse range of external and internal actors engaged in peacebuilding while interrogating the central issue of legitimacy in peacebuilding (Aguirre, 2010; Boege et al., 2009). Originating in the natural sciences, hybridity has long been employed in the humanities and social sciences to challenge hegemonic discourses and practices. There is no commonly accepted definition of hybridity as it applies to peacebuilding. In fact, the concept and its utility are highly contested. ${ }^{4}$ Nonetheless, hybridity in peacebuilding can be described as the process and the outcome of the contestation between different normative and socio-political systems which lead to the creation of a new system which is sufficiently distinct from its progenitors. In other words, hybridity occurs in the contested interaction between the domestic and the international peacebuilding agendas.

\section{Re-Framing Peacebuilding: From Liberal Peace to Hybridity}

There are two main reasons why the concept of hybridity has increasingly found fertile ground in peacebuilding. First, it captures the heterogeneity and diversity within societies as they come into contact with the international peacebuilding project. In contrast to the implicit assumption that conflict-affected societies are tabulae rasae that are open to externally-induced models of peace, the concept of hybridity recognizes the existence of domestic political orders with competing rules and claims to authority, power and legitimacy that interact and co-exist with various mixes of modern, indigenous, formal and informal traditions. Second, hybridity accepts that efforts to build liberal peace co-exist with and are mediated by domestic actors through "a complex mixture of local resistance, cooption, compliance and rejection" (Liden et al., 209: 588).

Thus, hybridity is a useful starting point for new ways of conceptualizing peacebuilding. It shifts the focus of peacebuilding from efficiency to legitimacy and links it more directly to the growing interest in statebuilding while challenging statebuilding's narrow focus on the formal institutions of the state. As has been noted, the challenge is "to search for ways and

\footnotetext{
${ }^{4}$ For further discussion of the application of hybridity to peacebuilding, see the special issue of the Journal of Peacebuilding and Development, 7(2): 1-114.
} 
means of generating positive mutual accommodation of state and customary non-state or civil society mechanisms and institutions - which in practice are not isolated domains anyway, but elements of a particular messy local socio-political context - so that new forms of political community might emerge that are more capable, effective, legitimate than those generated by narrowly conceived Western models of the state" (Boege et al., 2009: 608).

Equally importantly, allowing for hybridity has implications for tailoring external assistance for peacebuilding. Hybridity does not simply imply the need for greater collaboration, alignment, harmonization and synchronization of efforts among external and internal actors - although these can serve to address some of the current failures of mainstream peacebuilding strategies. Rather, it suggests that peacebuilding relations cannot be reduced to that of donors vs. recipients or national vs. international actors, but should be seen as part of a highly political process of negotiating multiple, and often competing, agendas across a full range of internal and external actors (Barnett and Zurcher, 2009). As Boege et al. (2009: 611) note,

The possibilities of externally influencing governance structures can be re-examined, shifting the focus from narrow models of state-building to understanding and engaging with non-state actors and institutions in hybrid political orders in an attempt to form political community not in ignorance of or even in opposition to local life-worlds, but embedded in them. At present, however, donors and other external actors tend to assume the role of teaching the politicians and people of so-called fragile states how to adopt Western state institutions effectively. There is much talk of ownership, but often this is not much more than lip service; in effect, locals are supposed to 'own' what outsiders tell them to - "local ownership clearly means 'their' ownership of 'our' ideas."

In other words, hybridity concerns both the processes and outcomes of peacebuilding and requires a shift in focus from externally-led models to open-ended, internally-driven but continually-negotiated political processes with uncertain and unforeseen outcomes. Such a shift in focus needs to be dynamic, conflict-sensitive and locally-grounded if it is to capture entrenched interests as well as changing realities in countries emerging from conflict.

Yet, the concept of hybridity, like peacebuilding itself, has so far found little traction among analysts and practitioners in conflict-affected countries - particularly in the South reflecting the entrenched North-South asymmetry in peacebuilding. Indeed, analytical perspectives that have informed peacebuilding policies and practices to date have largely been dominated by Western/Northern academics. With few exceptions, peacebuilding does not exist as a discrete field of study in Southern universities and research institutions. This is 
largely - though not exclusively - due to the overall weakness of the social sciences and the lack of a natural academic home for a transdisciplinary field like peacebuilding. Southern researchers and practitioners working on problems such as land reform, natural resource management, community-based recovery, traditional justice mechanisms or democratic governance do not necessarily label their work generically as peacebuilding. As a result, there is only a limited body of indigenous scholarship on peacebuilding to serve as a counterweight to the dominant peacebuilding discourses in the West. Instead, Southern scholars - especially from conflict-affected countries - have largely been engaged in debates originating in the West. Although Western policies and practices have come under strong criticism from Southern scholars, there is a shortage of systematic efforts that articulate countervailing analytical frameworks. The weakness of a robust body of empirical or theoretical literature by Southern analysts, researchers and academics has contributed to perpetuating the Western-bias in contemporary peacebuilding (IDRC, 2008). As has been noted by Liden et al. (2009: 593),

One of the notable aspects of scholarship on contemporary international peacebuilding is that the voices of the 'pacified', or the recipients of the liberal peace, are often absent. Increasingly, there is disagreement between those who support the liberal peace in its more coercive forms and those who seek to place greater weight on issues of local consent, selfdetermination, identity and sustainability.

Given the fact that Western academics (and especially the proponents of the problemsolving approach) have come to exercise growing influence among policy circles, externallyframed mainstream perspectives have dominated peacebuilding scholarship, policy and practice. Some scholars have identified this as a serious shortcoming of the field, noting that it raises

serious questions about the role of the academy in assisting or recycling associated policy mantras through 'pragmatic' policy-oriented research, which reproduces conservative versions of the liberal/neoliberal peace, rather than focusing on theoretical, empirical, ethical and methodological innovations that aim to produce emancipatory dynamics of peacebuilding. (Liden et al., 2009: 588)

It is in this context that hybridity can help to re-frame the discourses and practices that have shaped peacebuilding in the last two decades. The key question in peacebuilding is not about the validity of internal vs. external perspectives and agendas but their interplay, which has far-reaching consequences. Thus, hybridity is not an abstraction but a reality that needs to be investigated empirically. By challenging the misleading external vs. internal, formal vs. 
informal, modern vs. traditional dichotomies that have so far characterized peacebuilding discourse, policy and practice, hybridity forces a rigorous examination of the extent to which the goals, agendas and strategies pursued by multiple actors contribute to sustainable processes and outcomes on the ground.

The paucity of locally-generated research, analysis and scholarship on peacebuilding in conflict-affected countries remains a serious impediment to transforming the international peacebuilding agenda. But, if international peacebuilders are guilty of ignoring or undervaluing local dynamics and inputs, local peacebuilders are equally remiss in misreading and conflating international agendas and inputs because of their own lack of knowledge of the evolution of the international policy and practice in the last twenty years. As a result, the encounter of the local and the international is often based on faulty premises. In far too many cases, peacebuilding is reduced to technical models based on checklists and templates to avoid politics. In other cases, peacebuilding becomes highly politicized while lacking a common framework around which to mobilize competing interests and agendas. To overcome these shortcomings, hybridity in peacebuilding requires more systematic analysis and mapping of conflict dynamics by both international and local actors. But, it also requires credible platforms, institutions and mechanisms that can bring local and international actors around a common framework-both at the country and the global level. The following section is a quick review of two such mechanisms at the global level. While only illustrative, the review is intended to stimulate a critical reflection on ways of bridging the current chasm between local and international discourses, policies and practices.

\section{Bridging the Chasm at the Global Level}

As noted previously, managing the interactions between diverse external and internal actors is one of the major concerns in peacebuilding. How these relations are perceived, defined and aligned is an essential aspect of peacebuilding. Much of the mainstream literature defines engagement between locals and internationals in terms of promoting local ownership rather than a complex process of negotiation and contestation. Thus, the key mechanism for such engagement is seen to lie in better coordination through the use of numerous tools and strategies. This assumes that a higher degree of unity and coherence among both the domestic and the international actors, which is rarely the case. Discussions about coordination need to be preceded by a more accurate understanding of who and what 
should be coordinated and their respective interests and agendas. Since it cannot be assumed that domestic or international actors share similar agendas or common vision about peacebuilding, their interactions have to be intermediated from a peacebuilding lens. The next section reviews two mechanisms that are designed to bring conflict-affected countries together with international actors to identify more effective peacebuilding strategies. Both are experimental efforts and their impact on peacebuilding remains to be seen. In fact, there are serious concerns that they are state-centric initiatives that do not adequately take into account the competing interests and agendas both at the local and the international levels. Nonetheless, they constitute important innovations that merit closer attention.

\section{The UN's Peacebuilding Architecture}

One of the key institutional reforms aimed at managing the relations between conflictaffected countries and the multilateral system under the auspices of the United Nations was the creation of the UN's so-called Peacebuilding Architecture at the World Summit in 2005. The architecture consisted of the Peacebuilding Commission (PBC), the Peacebuilding Fund (PBF) and the Peacebuilding Support Office (PBSO). As an intergovernmental organ of the UN, the Commission was envisaged as a catalytic mechanism to redress the fragmented, piecemeal, erratic nature of international support to peacebuilding by establishing a set of new institutions with the explicit mandate to overcome these weaknesses and to better respond to local needs and realities (United Nations, 2000; 2004). In a nutshell, the PBC (and, by extension, the PBF and the PBSO) aimed to i) bring sustained attention to the pressing needs of countries emerging from conflict; ii) promote better coordination and coherence among the myriad actors involved in peacebuilding; iii) marshal resources for peacebuilding; and iv) increase the knowledge base for more effective peacebuilding policy and practice. The expectation was that the new architecture would serve as an interlocutor as well as an advocate for conflict-affected countries seeking international support. Moreover, there was an underlying assumption that, unlike other UN organs, the PBC would not be captive to narrow national interests but would be allowed to be guided by the needs of countries on its agenda.

Unfortunately, these high expectations were cut short as a result of the PBC's founding resolutions which reflected the deep political cleavages at the United Nations at the time. 
The PBC was created as an advisory body to both the Security Council and the General Assembly. As a result, the Commission lacked any independent authority or decision-making power over other bodies (Ponzio, 2007). Moreover, whereas the Commission had been intended "to provide an agile platform where all actors engaged in peacebuilding in a given context could discuss and agree upon a common strategy and priorities, during the negotiations, the PBC membership became significantly more fixed and formulaic" (Hearn et al., 2014). These early decisions had far-reaching consequences for the PBC's operations in countries that came on its agenda.

The first two countries to join the Commission's agenda were Burundi and Sierra Leone. Notwithstanding its built-in limitations and steep learning curve, the PBC initiated an extensive (and cumbersome) process of engagement with the national actors and other key stakeholders involved in both countries through the development of what was called the "integrated peacebuilding strategy," or IPBS. The country-specific IPBS process was intended to bring diverse actors to reach a shared understanding of conflict dynamics in each context and to be guided by jointly identified needs and priorities as the basis for more effective international responses. However, the IPBS process inevitably became intertwined with myriad other processes and mechanisms, adding another layer of complexity to the international engagement with national and local actors. Perhaps equally importantly, given its membership of 31 states with multiple intersecting agendas beyond the needs of conflictaffected countries, the PBC never rose up to becoming a consensus-based advisory body as had been hoped (Ponzio, 2007). Moreover, given its intergovernmental character, the PBC saw the government as its main interlocutor, thereby failing to engage effectively with other key national and local actors, especially the non-governmental sector.

Nonetheless, the IPBS process became the PBC's main instrument of engagement as new countries came on its agenda, reflecting a tendency towards path dependency rather than a willingness to better understand the political dynamics and peacebuilding challenges that are inevitably different in each conflict context (Tschirgi, 2010; Heemskerk, 2007). Indeed, with each successive country joining the PBC - Guinea-Bissau (2007), the Central African Republic (2008), Liberia (2010), and finally Guinea (2011) - the need for differentiated approaches became abundantly clear. Yet, each new country also exposed the deficiencies of the Peacebuilding Commission, not least its inability to adequately respond to the changing political dynamics in diverse conflict settings. 
The first five-year review of the PBC in 2010 highlighted many of the PBC's shortcomings (United Nations, 2012). Nonetheless, observers also pointed to some early wins, especially with respect to aid alignment and greater coherence among international actors. In Burundi, for example, the PBC was credited with engaging bilateral donors and multilateral agencies to better coordinate donor aid with the government and mobilizing over $\$ 680$ million through its advocacy efforts (Hearn et al., 2014, citing Smith, 2013). Similarly, in Sierra Leone, the PBC was seen to have provided political support to the Executive Representative of the Secretary General Von der Schulenburg in his efforts to coordinate a more coherent in-country strategy (ibid.). Yet, the mixed record of countries on the PBC's agenda in 2014 is telling: While none of the six countries is free of the risk of renewed conflict, there were serious relapses in Guinea-Bissau and the Central African Republic. The former witnessed a military coup in 2012, while the latter continues to experience an extended crisis. Perhaps more telling is the fact that the PBC is regularly bypassed as an effective instrument of international engagement in many other conflict-affected countries ranging from Afghanistan to Cote d'Ivoire and South Sudan.

It is beyond the scope of this paper to undertake an assessment of the PBC's effectiveness and impact. As the $10^{\text {th }}$ anniversary of the creation of the Peacebuilding Commission draws near, there will undoubtedly be many studies to evaluate the Commission's role in contributing to peacebuilding processes and outcomes. ${ }^{5}$ However, it is important to acknowledge that the IPBS process aimed to generate differentiated modalities of engagement which would allow for greater responsiveness to local dynamics. Equally importantly, the PBC has provided a platform whereby various governmental and intergovernmental actors could harmonize their peacebuilding interventions in ways that would better align with the fluid political conditions on the ground. In short, the PBC reflects a growing understanding of the need for a mechanism to provide timely support to critical political processes among key stakeholders, even if institutional UN politics have so far militated against giving PBC greater import (Jenkins, 2013; Berdal, 2009).

Yet, because the PBC's mandate is currently limited to only six countries on its agenda, it is clear that there is continuing need for other formal and informal mechanisms that can facilitate the range and breadth of engagement between international and local actors. Beyond the PBC, current mechanisms for engagement between international and local

\footnotetext{
${ }^{5}$ The PBC's five-year review focused largely on institutional issues.
} 
actors remain largely ad hoc, inadequate and often driven by powerful states. Interestingly, the growing security interest of major powers in state fragility and state building has led to an innovative mechanism that promises to circumvent UN politics through the New Deal.

\section{The New Deal for Engagement in Fragile States}

The New Deal is an arrangement between a group of 18 countries called the $g 7+$ and their international development partners which was adopted in Busan, South Korea in November 2011 during the $4^{\text {th }}$ High Level Forum on Aid Effectiveness. Unlike the PBC, which is a political body, the New Deal is focused on the aid relationship between donor and recipient countries. Established in 2010, the $\mathrm{g} 7+$ is a collective of countries (delicately identified as "fragile and/or in conflict-affected situations") which are committed to sharing experiences, developing strategies, and advocating for more effective peacebuilding and statebuilding. Because of the active role assumed by the $\mathrm{g} 7+$, which has its secretariat in Dili, Timor-Leste, the New Deal promises to strengthen the voice of conflict-affected and fragile countries at the international level.

The New Deal rests on the premise that development aid could support peacebuilding effectively only if it shifted from the previous "donor-to-recipient transfer of models, policies and practices - or using blueprint approaches to institutional reform - to an equal partnership between governments and development partners, based on dialogue and collaboration" (IDPS Secretariat, 2014). Thus, it asserts that aid should focus on the right priorities, country-owned and country-led processes of transition and resources that are targeted to build local capacities and systems.

The New Deal has identified five Peacebuilding and Statebuilding Goals (PSGs) as the basis to enable progress toward the Millennium Development Goals (MDGs) and to guide national as well as international efforts and resources. The PSGs consist of legitimate politics, to foster inclusive settlements and conflict resolution; security, to establish and strengthen people's security; justice, to address injustices and increase people's access to justice; economic foundations, to generate employment and improve livelihoods; and revenues and services, to manage and build capacity for accountable and fair service delivery. ${ }^{6}$

The New Deal has established new terms of engagement to support country-owned and country-led transitions out of conflict and fragility under the acronym FOCUS, which

\footnotetext{
${ }^{6}$ For extensive documentation on the New Deal, see http://www.newdeal4peace.org/.
} 
encompasses fragility assessments, one vision/one plan, compacts among key stakeholders, use of PSGs to monitor progress, and support for political dialogue and leadership. The New Deal also outlines a series of commitments to achieve better results, under the acronym TRUST (transparency, risk sharing, use and strengthening of country systems, strengthening capacities, and timely and predictable aid.)

Since its launch in 2011, there has been intense activity to operationalize the goals embodied in the New Deal in seven pilot countries: Afghanistan, Central African Republic, Democratic Republic of Congo, Liberia, Sierra Leone, South Sudan and Timor-Leste. This process is being accompanied by concerted efforts to develop new methodological and analytical tools to monitor the progress under the New Deal. Recognizing that many peacebuilding strategies are based on conflict analysis tools that were prepared by external analysts and experts, the New Deal has called for country-led studies on the causes and features of fragility and sources of resilience called the "fragility assessments" to serve as the basis for the "one vision/one plan" strategy under FOCUS. These periodic assessments are to be prepared by key national stakeholders and non-state actors based upon a harmonized methodology, including a fragility spectrum, to be developed by the $\mathrm{g} 7+$ and supported by international partners.

In preparation for a June 2014 Implementation Working Group Meeting in Sierra Leone to monitor progress toward the PSGs, a report was prepared to assess the main achievements of the New Deal based on two surveys and information drawn from other sources. The report identifies the New Deal's main achievements as follows:

First, more inclusive dialogue among governments, donors, and civil society has improved over the past three years on some countries. This has led to more attention to peacebuilding and statebuilding. [...] Second, aid is becoming more transparent. The survey findings demonstrate that donors are taking aid transparency seriously, and are improving their global systems and standards for reporting on development assistance. [...] Third, donor financing is more becoming integrated. (IDPS, 2014: 9-10)

Yet, the report also notes that while these results point to greater national leadership and some changes in donor behavior, "they fall short to a significant extent of the "paradigm shift' that is expected out of the New Deal. The change is slow and not systemic" (IDPS, 2014: 10.)

On paper, the New Deal seems like a step forward in giving the $g 7+$ a greater voice in agenda setting as well as strategic planning to redress the current asymmetric relations 
between conflict-affected and fragile countries and their development partners. It has considerable potential to do so provided it brings politically informed and locally generated analysis and needs assessments to the table based on serious consultations with key stakeholders at the country level. As has been noted,

The New Deal's particular value is to provide a framework for ensuring that the search for an acceptable political settlement is inclusive and based on shared understanding of both the deep-rooted and current drivers of fragility and sources of resilience. This approach ensures that dialogue does not limit itself to an elite pact to stop the conflict. Instead, the New Deal seeks to keep dialogue dynamic and at a high level, going beyond just a peace agreement and steering both national and international efforts to rebuild the country in a more resilient way. (IDPS, 2014: 21-22)

Currently, it is not evident that this is actually happening. Many of the analytical tools and frameworks that are being employed seem to imitate their international counterparts. Moreover, despite the constant refrain about country-specific context analyses as a way of averting conflict and fragility, two g7+ countries (Central African Republic and South Sudan) are engaged in violent civil conflict, with parts of Somalia continuing to experience high levels of insecurity and conflict. Thus, the 2014 Monitoring Report frankly states:

The New Deal has not been able to play an instrumental role in anticipating risks and supporting potential mitigation strategies in CAR and South Sudan. Nor is it currently providing a framework for dialogue between partners, or the identification of future pathways out of conflict.

Rather, New Deal implementation appears primarily focused on delivery of technical processes, and supporting technical dialogue on issues, such as aid effectiveness and results. Fragility Assessments, when undertaken, have struggled to gain political traction for their findings, as evidenced by the limited uptake of PSGs in country programming and the lack of a whole-of-government approach. Second, donor approaches to risk continue to be focused on fiduciary risk and project-level risk, with insufficient attention paid to using their programmes to support mitigation strategies for contextual and political risk. This is in spite of important shifts in risk policies at donor headquarters. (IDPS, 2014: 22)

The report further cautions that

[t] ] current approach to New Deal implementation presents a number of risks, including: lack of country ownership beyond the lead New Deal institutions; development of processes and instruments that are donor-driven rather than country-led; proliferation of parallel processes in environments that are already highly fragmented; and, lack of adaptation to the varying contexts faced by g7+ countries, including situations of conflict and extreme fragility. (IDPS, 2014: 24)

Despite its limitations, and just like the Peacebuilding Commission, the g7+ and the New Deal have opened up a new process that merits closer monitoring. Interestingly, however, it 
has been noted that since 2011 a rift emerged between the PBC and the International Dialogue on Peacebuilding and Statebuilding "largely over influence and authority in global peacebuilding policy" (Hearn et al., 2014: 7). Some PBC member states have expressed concerns over a Western-dominated agenda pursued by OECD donors in the IDPS which "subordinated development to security concerns" (ibid.). Yet the PBC has failed to come up with an institutional response to working with the g7+ countries and International Dialogue. As Hearn et al. have noted, "The potential result is an ever-growing network of donordominated peacebuilding 'compacts' and aid allocations on the ground without the buy-in of all relevant powers; and a PBC that risks being marginalized from much of the action in the field" (ibid.). The reality is that intergovernmental mechanisms like the PBC and the IDPS are inevitably limited by their institutional mandates, which militate against more radical transformation of the asymmetric relations between local and international actors, much less giving birth to an entirely new peacebuilding paradigm. Yet, it is also important to acknowledge that the entire peacebuilding agenda itself is under considerable pressure in light of the changing international peace and security context since 9/11 (Tschirgi, 2013).

\section{Conclusion}

As the previous sections demonstrated, there are sharp disconnects between myriad local and international actors in their understandings of and approaches to peacebuilding, which in turn contributes to the mixed record of peacebuilding. Accepting hybridity as a reality requires better understanding of the interests, capacities, needs and priorities of all actors involved in peacebuilding. To date, peacebuilding theory, policy and practice have been set back by the absence of strong "inside-out" perspectives on peacebuilding. In the last decade, a sizeable body of case studies on peacebuilding has been produced. These have provided in-depth analyses of conflicts in diverse contexts and examined the achievements and limitations of international peacebuilding - albeit primarily from the perspectives of outside analysts and external actors.

This paper provided a quick overview of the international peacebuilding project, presented key debates in the peacebuilding literature on the main features and limitations of that project, introduced the concept of hybridity as a way to ground international efforts within local dynamics in order to secure more sustainable processes and outcomes, and reviewed two key mechanisms seeking to bridge the chasm between local and international 
approaches to peacebuilding. The paper argued that peacebuilding involves the complex interplay between multiple internal and external actors which contributes to variegated outcomes in peacebuilding. The underlying premise has been that incorporating local perspectives would not only contribute to strengthening peacebuilding research, policy and practice, but would also serve as a corrective to the current stylized and formulaic discourses on peacebuilding.

As noted above, mainstream liberal peacebuilding has focused narrowly on reforming current practices. Liden et al. (2009: 594) have argued that it

may need to investigate ways of not just extending its moral responsibility over the citizen or subject or the non-liberal other, but engaging with other, probably non-Western/'modern' ontologies and epistemologies. It needs to find ways of building this confrontation or engagement into the peacebuilding process itself, in order to reconstruct a more politically hybridized form of peacebuilding, and certainly one that is better at representing, providing for respecting the rights and needs of post-conflict societies and communities. It also requires reflection on the need for an international social contract between peacebuilders, international officials, soldiers, aid workers, NGO personnel, development experts and a range of other experts and administrations with the full range of the recipients of peacebuilding (not just powerful local elites), in the absence of any national social contract.

The creation of new mechanisms such as the Peacebuilding Commission and the New Deal certainly do not involve a radical transformation of the current peacebuilding paradigm. They do, however, offer new platforms to bring diverse voices and approaches to the table. If sufficiently anchored in politically-informed and locally-grounded realities, such mechanisms might help to overcome the current biases of externally-driven peacebuilding research, policies and practices. One important remedy to more effective peacebuilding lies in meaningful and systematic incorporation of local perspectives, realities, needs and aspirations into peacebuilding analysis, policy and practice since current models and processes fail to capture the complexity of peacebuilding as experienced in different contexts. As has been argued throughout this paper, the question is not one of privileging one set of analysts or one set of actors over another. On the contrary, it is fully recognized that contemporary peacebuilding is - and will likely remain - a joint enterprise. The real question is how to improve that enterprise through research, policy development and practice that supports joint agenda setting, strategic planning and implementation. 


\section{References}

Anderson, Mary (1999), Do No Harm. Boulder. CO: Lynne Rienner Publishers.

Aguirre, Mariano; van der Borgh, Chris (2010), "Building Peace, States and Hybrids: International Operations in Post-conflict Countries," The Broker. Accessed on 15.08.2014, at http://www.thebrokeronline.eu/Articles/Building-peace-states-and-hybrids.

Baranyi, Stephen (ed.) (2008), The Paradoxes of Peacebuilding Post-9/11. Vancouver: UBC Press.

Barnett, Michael; Kim, Hunjoon; O'Donnell, Madalene; Sitea, Laura (2007), "Peacebuilding: What is in a Name?" Global Governance: A Review of Multilateralism and International Organizations, 13(1): 35-58.

Barnett, Michael; Zurcher, Christoph (2009), "The Peacebuilder's Contract: How External Statebuilding Reinforces Weak Statehood," in Roland Paris \& Timothy Sisk (eds.), The Dilemmas of Statebuilding: Confronting the Contradictions of Postwar Peace Operations. London: Routledge, 23-52.

Berdal, Mats (2009), Building Peace after War. London: The International Institute for Strategic Studies.

Boege, Volker; Brown, Anne; Clements, Kevin; Nolan, Anna (2009), "Building Peace and Political Community in Hybrid Political Orders," International Peacekeeping, 16(5): 599-615.

Chesterman, Simon (2007), "Ownership in Theory and in Practice: Transfer of Authority in UN Satebuilding Operations," Journal of Intervention and Statebuilding, 1(1): 3-26. DOI: 10.1080/17502970601075873

Cutillo, Alberto (2006), "International Assistance to Countries Emerging from Conflict: A Review of Fifteen Years of Interventions and the Future of Peacebuilding," International Peace Academy-IPA Policy Paper, February. Accessed on 15.08.2014, at http://www.ipinst.org/media/pdf/publications/cutillo e rpt.pdf.

Donais, Timothy (2009), "Empowerment or Imposition? Dilemmas of Local Ownership in PostConflict Peacebuilding Processes," Peace \& Change, 34(1): 3-26. DOI: 10.1111/j.14680130.2009.00531.x

Goodhand, J.; Atkinson, P. (2001), Conflict and Aid: Enhancing the Peacebuilding Impact of International Engagement: A Synthesis of Findings from Afghanistan, Liberia and Sri Lanka. London: International Alert.

Hearn, Sarah; Bujones, Alejandra Kubitschek; Kugel, Alischa (2014), The United Nations "Peacebuilding Architecture": Past, Present and Future. New York: Center on International Cooperation.

Heemskerk, Renske (2007), "The UN Peacebuilding Commission and Civil Society Engagement," Disarmament Forum, 2: 17-26.

IDPS - International Dialogue on Peacebuilding and Statebuilding (2014), New Deal Monitoring Report 2014. Document 01. Fifth International Dialogue Working Group Meeting on New Deal Implementation, 17 June 2014, Freetown, Sierra Leone. Accessed on 15.08.2014, at http://www.pbsbdialogue.org/newsandevents/specialevents/RD\%201\%20New\%20Deal\%20Monit oring\%20Report\%202014\%20FINAL.pdf.

IDRC - International Development Research Centre (2008), "International Development Research Centre and Peacebuilding Support Office Joint Conference Report." Ottawa, Canada, 10-11 December 2008.

Jenkins, Rob (2013), Peacebuilding: From Concept to Commission. London: Routledge. 
Liden, Kristoffer; Mac Ginty, Roger; Richmond, Oliver P. (2009), "Introduction: Beyond Northern Epistemologies of Peace: Peacebuilding Reconstructed?" International Peacekeeping, 16(5): 587598.

McCandless, Erin; Tschirgi, Necla (2010), "Strategic Policy Frameworks that Embrace Mutual Accountability for Peacebuilding: Emerging Lessons in PBC and non-PBC Countries," Journal of Peacebuilding and Development, 5(2): 20-46.

Newman, Edward (2009), "'Liberal' Peacebuilding debates," in Edward Newman, Roland Paris \& Oliver Richmond (eds.), New Perspectives on Liberal Peacebuilding. Tokyo: UN University Press, 26-53.

Newman, Edward; Paris, Roland; Richmond, Olivier P. (eds.) (2009), New Perspectives on Liberal Peacebuilding. Tokyo: UN University Press.

Ponzio, Richard (2007), "The United Nations Peacebuilding Commission: Origins and Initial Practice," Disarmament Forum, 2: 5-16.

Pugh, Michael (2013), "The Problem-Solving and Critical Paradigm," in Roger Mac Ginty (ed.), Routledge Handbook of Peacebuilding. London: Routledge, 11-24.

Richmond, Oliver (2006), The Transformation of Peace: Peace as Governance in Contemporary Conflict Ending. London: Palgrave Macmillan.

Richmond, Oliver (2009), "Becoming Liberal, Unbecoming Liberalism: Liberal local Hybridity via the Everyday as a Response to the Paradoxes of Liberal Peacebuilding," Journal of Intervention and Statebuilding, 3(3): 324-344. DOI: 10.1080/17502970903086719

Smith, Dan (2004), "Getting Their Act Together: Toward a Strategic Framework for Peacebuilding." Synthesis report of the Joint Utstein Study of Peacebuilding. Oslo: The Royal Norwegian Ministry of Foreign Affairs. Accessed on 15.08.2014, at http://www.regieringen.no/upload/kilde/ud/rap/2004/0044/ddd/pdfv/210673-rapp104.pdf.

Sørbø, Gunnar M.; Hauge, Wenche; Hybertsen, Bente; Smith, Dan (1998), “Norwegian Assistance to Countries in Conflict: The Lesson of Experience from Guatemala, Mali, Mozambique, Sudan, Rwanda and Burundi." Oslo: The Royal Ministry of Foreign Affairs. Accessed on 14.08.2014, at http://www.norad.no/en/tools-and-publications/publications/publication?key=109650.

Tadjbakhsh, Shahrbanou (ed.) (2011), Rethinking the Liberal Peace: External Models and Local Alternatives. London: Routledge.

Tschirgi, Necla (2004), "Post-Conflict Peacebuilding Revisited: Achievements, Limitations, Challenges," International Peace Academy-IPA Policy Paper, October. Accessed on 14.08.2014, at http://www.un.org/esa/peacebuilding/Library/Post Conflict Peacebuilding IPA.pdf.

Tschirgi, Necla (2013), "Securitization and Peacebuilding," in Roger Mac Ginty (ed.), Routledge Handbook of Peacebuilding. London: Routledge, 197-210.

United Nations (1992), "An Agenda for Peace: Preventive Diplomacy, Peacemaking and Peacekeeping." Report of the Secretary-General pursuant to the statement adopted by the Summit Meeting of the Security Council on 31 January 1992. A/47/277-S/2411. New York: United Nations. Accessed on 14.08.2014, at http://www.unrol.org/files/A 47 277.pdf.

United Nations (2000), "Report of the Panel on United Nations Peace Operations" (The Brahimi Report). General Assembly and Security Council. Document A/55/305-S/2000/809, 21 August 2000. Accessed on 14.08.2014, at http://www.unrol.org/files/brahimi report peacekeeping.pdf.

United Nations (2004), "A More Secure World: Our Shared Responsibility. Report of the High Level Panel on Threats, Challenges and Change." General Assembly. Document A/59/565, 2 December 2004. 
http://www.un.org/en/events/pastevents/a more secure world.shtml.

United Nations (2012), 2012 Annual Report. UN Peacebuilding Support Office. Accessed on 15.08.2014, at http://www.un.org/en/peacebuilding/pbso/pdf/2012PBSO-AnnualReportFinal.pdf.

Uvin, Peter (1999), "The Influence of Aid in Situations of Violent Conflict." Prepared for the Development Assistance Committee Informal Task Force on Conflict, Peace, and Development Cooperation, Paris: OECD, September 1999. Accessed on 15.08.2014, at http://www.oecd.org/officialdocuments/publicdisplaydocumentpdf/?cote=DCD(2000)16\&docLan guage=En.

Waller, Peter (2000), "Lessons Learned from Evaluations: Findings from a Recent Evaluation of German Development Co-Operation in Conflict Situations in Six Countries". Prepared for the seminar on "After War Reconciliation and Democratisation in Divided Societies - Lessons Learned," Solstrand, Norway, 27-29 March. 